
330.4

Original Scientific Paper

\title{
Comparative Analysis of the Regional Efficiency in Serbia: DEA Approach
}

\author{
Article history: \\ Received: 25 June 2020 \\ Sent for revision: 27 June 2020 \\ Received in revised form: 17 August 2020 \\ Accepted: 4 September 2020 \\ Available online: 19 October 2020
}

Abstract: The main aim of the paper is to offer a statistical identification of differences in efficiency between Serbian regions. The regional resources covered by the analysis are presented in the form of infrastructure, investment in new fixed assets and employment levels. For the researching purpose, data envelopment method (DEA) is used as a major component in identifying regions that use their resources effectively. This approach of mathematical programming optimization tends to evaluate the efficiency of the analyzed regional spatial aspects. Moreover, studying regional differences and generally spatial efficiency creates a significant basis for mapping key problems of regional development in Serbia and provides important guidelines for the creation and implementation of regional policies.

Keywords: data envelopment analysis (DEA), efficiency, Republic of Serbia, regional disparities

\section{Komparativna analiza regionalne efikasnosti u Srbiji: DEA pristup}

Apstrakt: Osnovni cilj rada je da ponudi statističku identifikaciju razlika u efikasnosti između srpskih regiona. Regionalni resursi obuhvaćeni analizom predstavljeni su u formi infrastrukture, ulaganja u nova osnovna sredstva i nivoa zaposlenosti. Za svrhu ovog istraživanja kao glavna komponenta $u$ identifikovanju regiona koji efikasno koriste svoje resurse koristi se metod obuhvatanja podataka (DEA). Ovakav pristup optimizacije matematičkog programiranja omogućava da se proceni efikasnost analiziranih regionalnih

\footnotetext{
${ }^{1}$ University of Kragujevac, Faculty of Economics, Serbia, ljubivojeradonjic@yahoo.com
} Industrija, Vol.48, No.2, 2020 
prostornih aspekata. Štaviše, proučavanje regionalnih razlika i opšte prostorne efikasnosti čini značajnu osnovu za mapiranje ključnih problema regionalnog razvoja u Srbiji i pruža važne smernice za kreiranje i sprovođenje regionalnih politika.

Ključne reči: analiza obuhvatanja podataka, efikasnost, Republika Srbija regionalni dispariteti

\section{Introduction}

Identifying the level of development and researching socio-economic disparities between territories has been one of the main focuses in economic research in the past decades. It is widely considered that the degree of economic development often differs over the regions.

Regional development policy manages with available resources in aim to gain regional growth and development, and/or to redistributes any undesirable income gaps. Moreover, planning the allocation of the country's economic potentials and measuring the archived efficiency in subnational regions is an essential framework for creating effective public policy (Kataoka, 2018).

In an aim to have a clear review of very different availability of territorial resources between regions the paper explores a basic set of economic factors in territorial units. The concept of territorial resources summarizes the endogenous sources of economic development and provides a solid, homogenous theoretical framework through which present regional development paths can be explained and policy implications can be identified.

This survey develops a model of the concept of region potentials. More precisely, it explores the composition of regions' development factors. The structure of territorial resources across regions is accounted for, with to aim of understanding spatial imbalances and factors fostering territorial capital improvement across Serbian regions.

The main subject of the research is the efficiency of 25 regions in Serbia, measured through the relative success of utilization of their resources. More particularly, this paper tends to investigate and compare regional efficiency by implementing the DEA approach. The main aim of the survey is to identify spatial disparities in efficiency according to the analyzed regional inputs and output.

The article is organized as follows. Firstly, the outcome of relevant empirical research on the DEA regional analysis is presented. There then follows a representation of the applied methodology of the research and an explanation 
of the data used, with the results of the research then presented. Lastly, the conclusions of the article are summarised and further direction for research in the area is outlined.

\section{Literature review}

In literature, the question of spatial efficiency has been analyzed in various manners. According to that, DEA has been used in various fields for decision making about optimizing inputs and outputs in terms of their more efficient utilization. Analysis of the countries' various sectors, regions' infrastructure, and other fields are made in the macroeconomics level. The spatial frontier analysis has become a powerful quantitative and analytical tool for measuring and evaluating performance in various fields. Several studies have been done in the field of spatial frontier analysis to evaluate a country's regional efficiency in its usage of capital and other resources.

Relying on data for private and public investments and the labour force in measuring the level of GDP per capita, Halkos and Tzeremes (2010) conclude that there is a significant inefficiency in the regional policies of the Greek prefectures from 2003 to 2006. Fazio, Piacentino, and Vasallo (2006) have used a specific dataset of regional social and economic indicators to evaluate the economic results of Italian regions with respect to both GDP per capita and competitiveness. A prominent conclusion of their survey is that regions with better institutional background archive better results. Skare and Rabar (2014) have concluded that regional efficiency scores of Croatian regions differ significantly, which proves strong interregional socio-economic disparities.

Surveying on the current expenditures of the municipal units, and their outputs by key public services provided, Radulović and Dragutinović (2015) evaluated the extent of regional inefficiency in Serbia using a sample of 143 local selfgovernments in 2012. Krstić and Mimović (2018) investigated the efficiency of Serbia's regions in terms of research investments and innovation results. In the paper, they offer the information on which aspects of the institutional framework need to be improved and which inputs should increase or decrease in order for more innovation to be archived.

Some interesting methods for quantitative measurement of innovation performance are presented in surveys of Fritsch and Slavtchev (2011), Hudec and Prochádzková (2013), Zuo and Guan (2017). In another interesting approach, Zemtsov and Kotsemir (2019) showed that DEA could be a widespread tool for surveying the region's innovative results. Wang and Weichiao (2007) investigated the production function of the R\&D framework on the inter- 
country basis. Further, using a sample of 22 developed and developing states, Sharma and Thomas (2008) tested a relative efficiency in regard to R\&D investment.

Collecting different conclusions of the theoretical and empirical literature, Rabar (2017) noted that any of the various DEA approaches could be very indicative of specific issues of interest, but none of them can be determined as the best solution. Nevertheless, they all only offer a background for further surveys that might result in the advancement for the purpose of the investigation of economic efficiency.

DEA method has its limits, but it is very important to outline the potential for various manners in implementing this model in analyzing regional efficiency. Particularly, this concerns the selection of inputs and outputs which are tested in the specific DEA approach. In the following, the research methodology and building the DEA model are presented.

\section{Research methodology}

From the historical perspective, it could be generally accepted that DEA was introduced by Charnes et al (1978). By its definition, it makes a linear production function based on which it is possible to measure the relative efficiency of the DMUs observed. The main feature of the DEA approach comes from its nonparametric method, which does not require the ex-ante definition of the production function. With the DEA, the problem of determining an explicit production function is overcome by combined assumptions about factors. Another important specificity is that the DEA allows multiple input-outputs to be considered simultaneously without ever testing the distribution of the data collected.

The DEA model can be tested as an output-oriented model that maximazes outputs while satisfying at least given input levels, and as an input-oriented model that minimizes inputs without the need for more than any observed illumination value. An output-oriented model was used in this paper.

It is important to note that DEA results indicate the relative rather than the absolute effectiveness of each DMU under consideration. The DEA rates the DMU as effective when it has the best ratio of any output to any input and this generalizes the importance of the outputs/inputs considered.

An output-oriented DEA identifies a frontier DMU by determining the best input/output combination that produces maximum outputs using minimum inputs for the observation set analyzed. The efficiency of all other DMUs is 
detected as a relative value using a relevant frontier as a reference. While some basic mathematical expressions of the DEA method was developed by Banker et al (1984), for the purpose of this survey, the efficiency of each DMU is computed as (Aristovnik, 2014):

$$
\operatorname{Max} \phi_{r}
$$

$$
\begin{gathered}
\sum_{j=1}^{25} \lambda_{j} X_{i j} \leq X_{\text {ir }} \text { for } i=1,2,3 \\
\sum_{j=1}^{25} \lambda_{j} Y_{j} \geq \phi_{r} Y_{r} \\
\sum_{j=1}^{25} \lambda_{j}=1 \\
\lambda_{j} \geq 0 \text { for } j=1,2,3 \ldots 25 \\
\phi_{r} \geq 0
\end{gathered}
$$

DEA calculates the comparative ratio of outputs to inputs for each DMU, with the result from $0 \%$ to $100 \%$. According to methodology, a DMU with a value of less than $100 \%$ can be rated as inefficient compared to other units.

The optimal result of $\phi_{r}$ should be greater than or equal to 1 . This result applies to the overall inverse efficiency of the $D M U_{r}$, which describes the actual proportion by which Region $r$, can increase its level of the observed economic result.

Equations (2) and (3) can be described as weighted averages compared to Equations (4) and (5). Furthermore, when the $\lambda_{j}$ is replaced by $\lambda_{j}{ }^{*}$, left side of Equations (2) and (3) can be marked as the main inputs and main output for territorial unit $r$. Equation (2) defines that every main input should be less than or equal to the actual level of that input in region $r$. Equation (3) suggests that

Industrija, Vol.48, No.2, 2020 
the main output should be greater than or equal to the real output level in region $r$.

Equation (4) summarizes that the weights are summed up to 1, so the main outputs and inputs can be described as weighted averages of the corresponding quantities in $r$ 's reference regions, which implies that the value of $\lambda_{j}$ is eaqual to 0 . Further, these indications follow to describe the production process in the context of the variable return to scale (VRS), which basically means that efficiency of an extra unit of input variable can varry with the magnitude of the specific teritory.

Therefore, the main goal of an optimal value for region $r$ can be achieved in two manners: to spend the same or less level of the resources regarding a specific level of the output; or to produce the same or more output with the same level of the utilized resources.

\subsection{Research Sample and Specification of the DEA model}

In regional disparities analyses, it is generally prescribed to use variables that reflect and determine a wider socio-economic context of the considered geographical territories (Schaffer et. al., 2011). Following the Bronzini and Piselli (2009), regional production can be described by the region's capacities in the immobile resources. An important prerequisite of regional economic development is related to the efficiency of resource utilization. If some regional factors are well used, there is a better potential to fostering regional growth through improved efficiency of these factors.

In this article three input variables are included: infrastructure, new investments in the fixed assets, and share of employees. Viewed through the economic realities of regional units, higher levels of production, growth, and development are most often achieved through the more efficient use of available factors. In the paper, the level of regional development is monitored through a commonly used indicator of the GVA per capita. This variable expressed in thousands of the local currency units is used as an output variable.

Infrastructure input is evaluated upon the formula proposed by Galinienè and Dzemydaitè (2012):

$$
I_{i}=\frac{p_{i}}{r_{i}}+\frac{r_{i}}{a_{i}}
$$

where:

$$
r_{i} \text { - length of roads in region } i(\mathrm{in} \mathrm{km}) \text {; }
$$




$$
\begin{aligned}
& p_{i} \text { - population of region } i \\
& a_{i} \text { - size of the region } i \text { (in sq. } \mathrm{km} \text { ). }
\end{aligned}
$$

New investments are presented as new investment in the fixed assets per capita. Human capital in the region is evaluated through the percentage of employees in the total population of the specific region.

All data used in this research were derived from the database of the Statistical Office of the Republic of Serbia (2019). As it usually for an application of this approach, a cross-section analysis is applied. It means that each DMU, or region in this model, is being observed only once, according to data for 2017. As the values of the included indicators vary considerably, the variable returns of scale as a type of frontier scale was applied to the model.

One of the important steps before running the DEA is to do a correlation test. All considered indicators, three inputs and only one output should be selected by correlation and with an acceptable level of significance. Table 1 shows the results of the correlation test.

Table 1. Correlation of input variables with output variable (GVA per capita)

\begin{tabular}{|l|c|c|c|}
\hline & Infrastructure capital & Investments per capita & Share of employees \\
\hline Correlation & 0.5159 & 0.7461 & 0.9223 \\
\hline Significance $^{*}$ & 0.0083 & 0.0000 & 0.0000 \\
\hline * level of significance between $1 \%$ and $5 \%$ \\
\hline
\end{tabular}

Source: Author, elaboration based on data from the Statistical Office of the Republic of Serbia (2019)

According to the results of the correlation test, it is obvious that relationships between the indicators used in the survey are significant at the 0.01 level (2tailed), exclude for the relation between infrastructure capital and output variable, where the correlation is significant at 0.05 level (2-tailed). Therefore, all input variables are incorporated into the model.

\section{Results}

The first step of the analysis is to consider the extent of regional development as measured by the GDP per capita. Fig 1 represents the GVA per capita for each of the 25 regions included in the survey. 
Figure 1. GVA per capita (in thousand Icu), 2017.

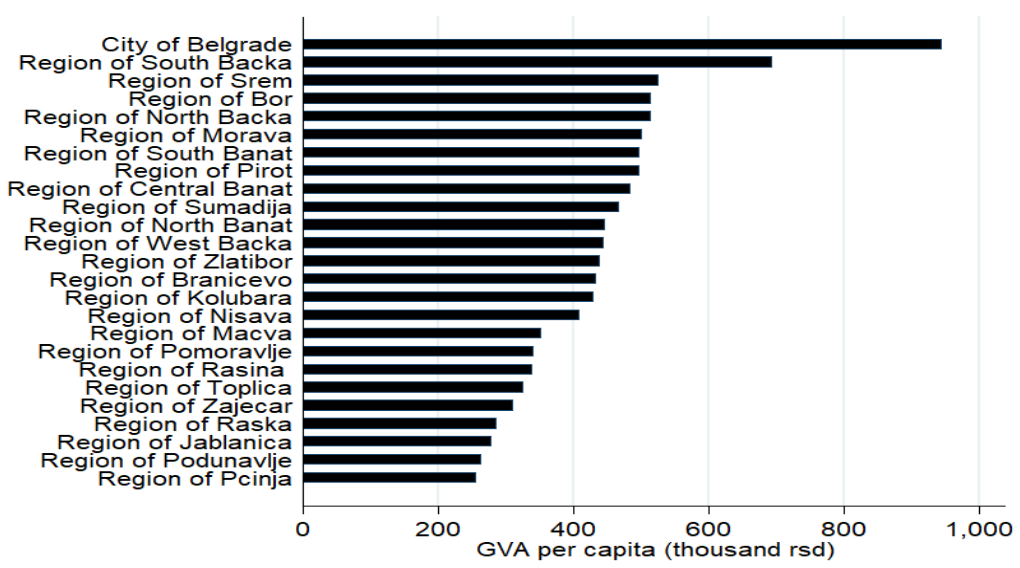

Source: Author, elaboration based on data from the Statistical Office of the Republic of Serbia (2019)

The highest GVA per capita or $40.4 \%$ of national GVA per capita has the city of Belgrade. Then follow the region of South Backa with $10.9 \%$ of national GVA per capita.

Considering other regions, it is apparent that five territorial units of Northern Serbia are in the group of first 10 regions according to the analyzed value of GVA per capita. The three regions: Jablanica, Podunavlje and Pcinja have the lowest value, with a value of only $0.9 \%, 0.7 \%$ and $0.1 \%$ of national GVA per capita, respectively.

The comparative analysis of Serbian regions' efficiency relies on the mathematical equation of the output-oriented DEA model. As it was mentioned, this approach is based on a variable return of scale. The model was tested through STATA .12 statistical software. Assuming that infrastructure capital can be presented as $I N P U T_{1}$, investments per capita as $I N P U T_{2}$, the share of employees as $I N P U T_{3}$, and GVA per capita as $O U T P U T_{0}$, then the model specification can be written as follows:

$$
\begin{aligned}
& \text { dea INPUT } \text { INPUT }_{2} \text { INPUT }_{3} \\
& =\text { OUTPUT }_{0} \text { rts }(\text { vrs }) \operatorname{ort}(o)
\end{aligned}
$$

where: 
$r t s(v r s)$ - variable return of scale;

$\operatorname{ort}(o)$ - output-oriented.

Table 2 represents the main outcomes of the DEA test, and it represents efficiency score, a rank of regions and type of return of scale.

Table 2. VRS - Output oriented DEA efficiency results

\begin{tabular}{|c|c|c|c|}
\hline Regions & Theta (Efficiency Score) & Rank & Return of Scale \\
\hline City of Belgrade & 1 & 1 & 0.000000 \\
\hline Region of South Backa & 1 & 2 & 0.000000 \\
\hline Region of South Banat & 1 & 3 & 0.000000 \\
\hline Region of Bor & 1 & 4 & 0.000000 \\
\hline Region of Pirot & 1 & 5 & 0.000000 \\
\hline Region of Central Banat & 1 & 6 & 0.000000 \\
\hline Region of West Backa & 1 & 7 & 1.000000 \\
\hline Region of Zlatibor & 1 & 8 & 0.000000 \\
\hline Region of Pcinja & 1 & 9 & 1.000000 \\
\hline Region of Morava & 0.99328 & 10 & -1.000000 \\
\hline Region of Jablanica & 0.979031 & 11 & 1.000000 \\
\hline Region of Srem & 0.922091 & 12 & 1.000000 \\
\hline Region of North Banat & 0.909638 & 13 & 1.000000 \\
\hline Region of Kolubara & 0.887969 & 14 & 1.000000 \\
\hline Region of Branicevo & 0.872273 & 15 & 1.000000 \\
\hline Region of Pomoravlje & 0.860067 & 16 & 1.000000 \\
\hline Region of North Backa & 0.859554 & 17 & 1.000000 \\
\hline Region of Sumadija & 0.858575 & 18 & 1.000000 \\
\hline Region of Raska & 0.792974 & 19 & 1.000000 \\
\hline Region of Macva & 0.766583 & 20 & 0.000000 \\
\hline Region of Toplica & 0.761724 & 21 & 0.000000 \\
\hline Region of Nisava & 0.761061 & 22 & 1.000000 \\
\hline Region of Rasina & 0.730363 & 23 & 0.000000 \\
\hline Region of Zajecar & 0.701798 & 24 & 0.000000 \\
\hline Region of Podunavlje & 0.604979 & 25 & 1.000000 \\
\hline Average & 0.890478 & - & - \\
\hline
\end{tabular}

Source: Author, elaboration based on data from the Statistical Office of the Republic of Serbia (2019)

The outcome of DEA analysis implies there are 9 regions in Serbia, who utilize effectively their potentials. Alternatively, it is $36 \%$ of the total number of regions. The average efficiency score is 0.890478 . These 9 efficient regions could be defined as frontiers in the analyzed group of observed territorial units.

For instance, in another previous survey, but with a different set of inputs and outputs, Martić and Savić (2001) explored how well regions in Serbia utilized their resources. Regarding to their research, in an output-oriented model, and with the CCR DEA approach, they identified 17 of 30 regions as efficient. 
Regarding Table 2, the most efficient regions are the city of Belgrade, South Banat, South Backa, Zlatibor, Bor, Pirot, Pcinja, Central Banat and West Backa. According to the DEA score, the most five inefficient Serbian regions are those of Podunavlje, Zajecar, Rasina, Nisava, and Toplica. It is notable that, the region of Morava with an efficiency score of 0.99328 , and the region of Jablanica with an efficiency score of 0.979031 are two regions that are very close to be efficient. Also, according to available inputs, the region of Srem, and the region of North Banat can improve their GVA per capita for less than $10 \%$.

Also, in the fourth column of Table 1, there are results for VRS. From 25 observed regions, 13 show an increasing return of scale, then follow 11 regions with a constant return of scale. It is notable that only the region of Morava archives a decreasing return of scale.

\section{Discussion}

It is also interesting to analyze these results of the DEA through the geographical distribution. The aim of this section is to see if there are any significant differences in efficiency when looking at larger territorial groups, for example between Northern Serbia and Southern Serbia. Fig 2 shows the regions with associated efficiency score results.

Figure 2. Spatial distribution of efficiency scores of Serbia, 2017.

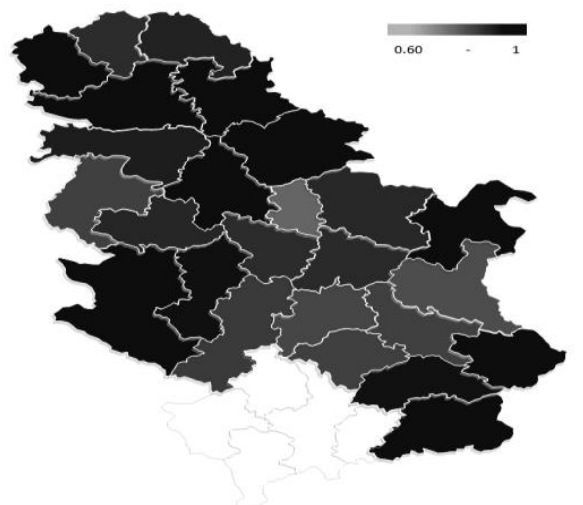

Source: Author, elaboration based on the DEA efficiency score results 
Fig 2 shows that the regions with higher efficiency scores are located in the Northern Serbia (South Backa, South Banat, Central Banat and West Backa) and the city of Belgrade, as a separate territorial unit. Avlijas and Bartlett (2011) suggest the centralization of resources allocation that is apparent in Serbia for decades has been the main reason of the economic success of the regions in the core.

There are some exceptions in the case of the following regions: Zlatibor (Western Serbia and Sumadija), Bor (Southern and Eastern Serbia), Pirot and Pcinja (Southern and Eastern Serbia), because these four regions are also efficient with the DEA score equal 1 . It is indicative that most inefficient regions are located in Southern and Eastern Serbia.

Further analysis may rely on making the groups of regions according to their efficiency scores. Fig 3 indicates the division of the regions into 4 groups, based on two criteria: GVA height per capita and value of efficiency score.

Figure 3. GVA and efficiency scores at the regional level, 2017.

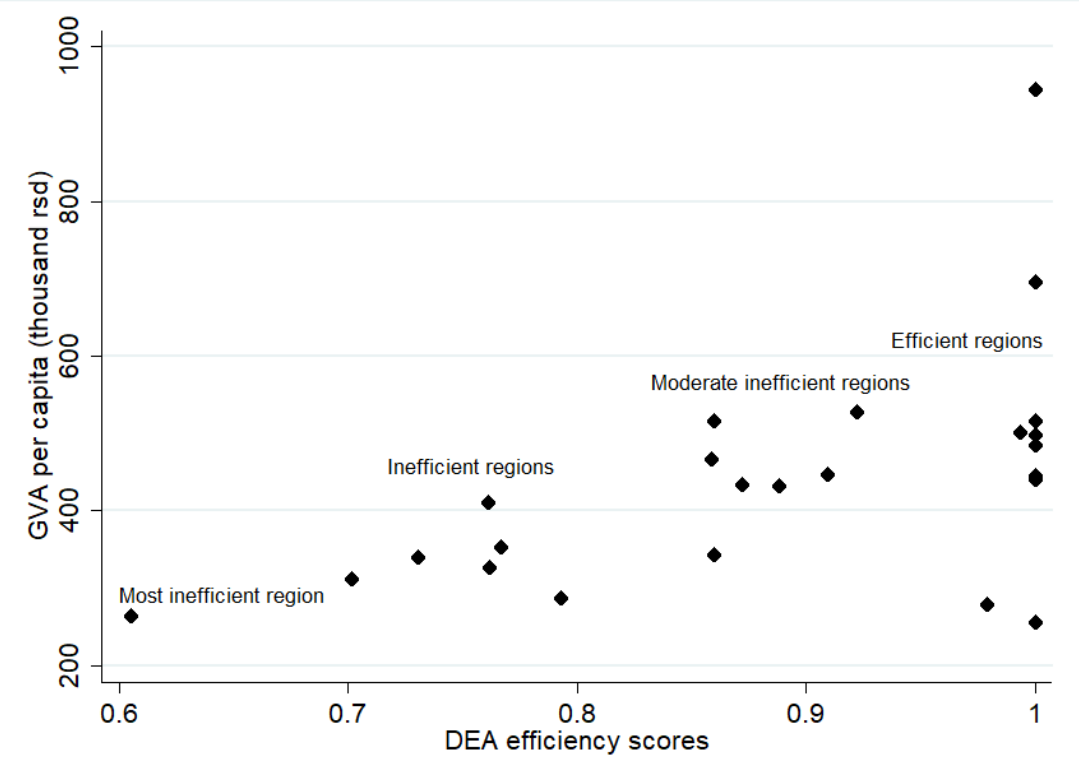

Source: Author, elaboration based on data from the Statistical Office of the Republic of Serbia (2019) and on the DEA efficiency results

Some of the observed territorial units: South Backa, West Backa, South Banat, Central Banat (Northern Serbia), Zlatibor (Western Serbia and Sumadija), Bor, 
Pirot, and Pcinja (Southern and Eastern Serbian), and the city of Belgrade are efficient regions. Also, the group of the efficient regions is consisted of the region of Morava with the value of the GVA per capita $501.000 \mathrm{lcu}$, and efficiency score equal to 0.99328 , and the region of Jablanica with the value of GVA per capita $278.000 \mathrm{lcu}$, and efficiency score equal to 0.979031 .

Further, Srem, North Banat, North Backa, Kolubara, Sumadija, Pomoravlje (Western Serbia and Sumadija) and Branicevo (Southern and Eastern Serbia) create a group of moderate inefficient regions. The average efficiency score of this group is 0.881542 , which means that these regions can improve their average GVA per capita for almost $12 \%$ according to their actual inputs.

The group of the less efficient regions is composed of six areas, i.e. Raska, Rasina, Macva (Western Serbia and Sumadija), Toplica, Nisava, and Zajecar (Southern and Eastern Serbia). The average theta coefficient of this group is 0.731355 and it indicates that these regions use their resources with $73 \%$ of efficiency.

The most inefficient region is Podunavlje with an efficiency score equal to 0.604979 . This territorial unit can increase regional GVA per capita by almost $40 \%$ using the resources at disposal.

\section{Conclusions}

The paper presents the results of the DEA and provides a basis for explaining regional differences. Built on the principles of mathematical programming, DEA offers a method for innovative testing of a manufacturing function in economics. Relying on the non-parametric feature of the DEA approach, several baseline statistical assumptions were avoided and the results were estimated directly based on the used indicators. Also, the results of the DEA method are very suitable for conducting comparative analyzes. Due to the aforementioned benefits, the DEA is used in various models of social and economic studies that aim to comparatively evaluate a certain number of units.

Research insights are focused on the presentation of regional disparities. According to the empirical aspect of this paper, it can be concluded that about one-third of the analyzed regions in Serbia are efficient. The average DEA score is 0.89 , which implies that 25 observed regions allocate their potentials at $89 \%$ of efficiency. With the city of Belgrade excluded, it should be pointed out that regions of Northern Serbia are the most developed. The most inefficient territorial unit uses resources at only $60 \%$, which means that there is a huge potential for more efficient usage of the region's inputs. Observed through a wider map, the most inefficient regional parts are those in Eastern and Southern 
Serbia. It is apparent that these regions could use their resources more efficiently from $15 \%$ to $30 \%$, approximately.

Additionally, it should be noted that this approach also has disadvantages. First of all, besides evaluating the relative efficiency of a particular unit in the observed group, it does not value its absolute efficiency in any way. Further, the DEA approach is based on the extreme performance values of each unit compared to the performance of the most efficient unit in the group. It is this disadvantage that makes this method more sensitive to the database being used and the possible errors that occur during testing.

Despite its limitations, the DEA approach presents a useful method to test economic efficiency. In that sense, for some future research of Serbia's regions efficiency another input and output indicators can be selected and rated as well.

\section{Conflicts of Interest}

"The author declares no conflict of interest".

\section{References}

Andronik, A. (2014). Efficiency of the R\&D Sector in the EU-27 at the Regional Level: An Application of DEA. Lex Localis, 12(3), 519-531. doi: 10.4335/12.3.519531(2014)

Avlijas, S., \& Bartlett, W. (2011). The Political Economy of Decentralisation and Regional Policy in Serbia: Choices and Outcomes. LSEE Papers on Decentralisation and Regional Policy, Research Paper No. 3

Banker, R. D., Charnes, A., Cooper, W. W. (1984). Some Models for Estimating Technical and Scale Inefficiecies in Data Envelopment Analysis. Management Science, 30(9), 1078-1092. doi: 10.1287/mnsc.30.9.1078

Bronzini, R., \& Piselli, P. (2009). Determinants of long-run regional productivity with geographical spillovers: The role of R\&D, human capital and public infrastructure. Regional Science and Urban Economics, 39(2), 187-199. doi:10.1016/j. regsciurbeco.2008.07.002.

Charnes, A., Cooper, W.W., \& Rhodes, E. (1978). Measuring the efficiency of decision making units. European Journal of Operational Research, 2(6), 429-444. doi: 10.1016/0377-2217(78)90138-8

Fazio, G., Piacentino, D., \& Vassallo, E. (2006). Regional Disparities and Public Policies in Italy: Some Considerations in Light of a Performance Analysis. ERSA conference papers ersa06p439, European Regional Science Association.

Fritsch, M., \& Slavtchev, V. (2011). Determinants of the Efficiency of Regional Innovation Systems. Regional Studies, 45(7), 905-918. doi: 10.1080/00343400802251494

Industrija, Vol.48, No.2, 2020 
Galinienè, B., \& Dzemydaitè, G. (2012). Spatial Data Envelopment Analysis Method for the Evaluation of Regional Infrastructure Disparities. Social Technology, 2(2), 390-403.

Halkos, G. E., \& Tzeremes, N. G. (2010). Measuring regional economic efficiency: the case of Greek prefectures. The Annals of Regional Science, 45(3), 603-632. doi:10.1007/s00168-009-0287-6

Hudec, O., \& Prochádzková, M. (2013). The Relative Efficiency of Knowledge Innovation Processes in EU Countries. Studies in Regional Science, 43(1). 145-162, doi: $10.2457 /$ srs. 43.145

Kataoka, M. (2018). Inequality convergence in inefficiency and interprovincial income inequali-ty in Indonesia for 1990-2010. Asia-Pacific Journal of Regional Science, 2(2), 297-313. doi:10.1007/s41685-017-0051-3

Krstić, A., \& Mimović, P. (2018). Measuring Efficiency of the Serbian National Innovation System: DEA Approach. EBM - Contemporary Issues in economics, Business and Management (521-527). Kragujevac: Faculty of Economics.

Martić, M., \& Savić, G. (2001). An application of DEA for comparative analysis and ranking of regions in Serbia with regards to social-economic development. European Journal of Operational Research, 132(2), 343-356. doi:10.1016/S03772217(00)00156-9

Rabar, D. (2017). An overview of data envelopment analysis application in studies on the socio-economic performance of OECD countries. Economic Research Ekonomska istraživanja, 30(1), 1770-1784.doi:10.1080/1331677X.2017.1383178

Radulović, B., \& Dragutinović, S. (2015). Efficiency of local self-governments in Serbia: an SFA approach. Industrija, 43(3), 123-142. doi:10.5937/industrija43-8846.

Schaffer, A., Simar, L., \& Rauland, J. (2011). Decomposing regional efficiency. Journal of Regional Science, 51(5), 931-947. doi: 10.1111/j.1467-9787.2011.00731.x

Sharma, S., \& Thomas, V. J. (2008). Inter-country R\&D efficiency analysis: An application of data envelopment analysis. Scientometrics, 76(3), 483-501. doi: 10.1007/s11192-007-1896-4

Skare, M., \& Rabar, D. (2014). Regional efficiency assessment using dea window analysis. Economic computation and economic cybernetics studies and research / Academy of Economic Studies, 48(4), 39-61.

Statistical Office of the Republic of Serbia (2019). Municipalities and Regions of the Republic of Serbia, 2018. Retrieved from: http://publikacije.stat.gov.rs/ G2018/ PdfE/G201813045.pdf

Statistical Office of the Republic of Serbia (2019). Regional Gross Domestic Product, Region and areas of the Republic of Serbia, 2017. Regional Accounts, Working Paper No. 107

Wang, C. E., Weichiao, W. (2007). Relative efficiency of R\&D activities: A cross-country study accounting for environmental factors in the DEA approach. Research Policy, 36(2), 260-273. doi: 10.1016/j.respol.2006.11.004

Zemtsov, S., \& Kotsemir, M. (2019). An assessment of regional innovation system efficiency in Russia: the application of the DEA approach. Scientometrics, 120(2), 375-404. doi: 10.1007/s11192-019-03130-y

Zuo, K., \& Guan, J. (2017). Measuring the R\&D efficiency of regions in a parallel DEA game model. Scientometrics, 112(1). 175-194. doi: 10.1007/s11192-017-2380-4 